Provided for non-commercial research and education use. Not for reproduction, distribution or commercial use.

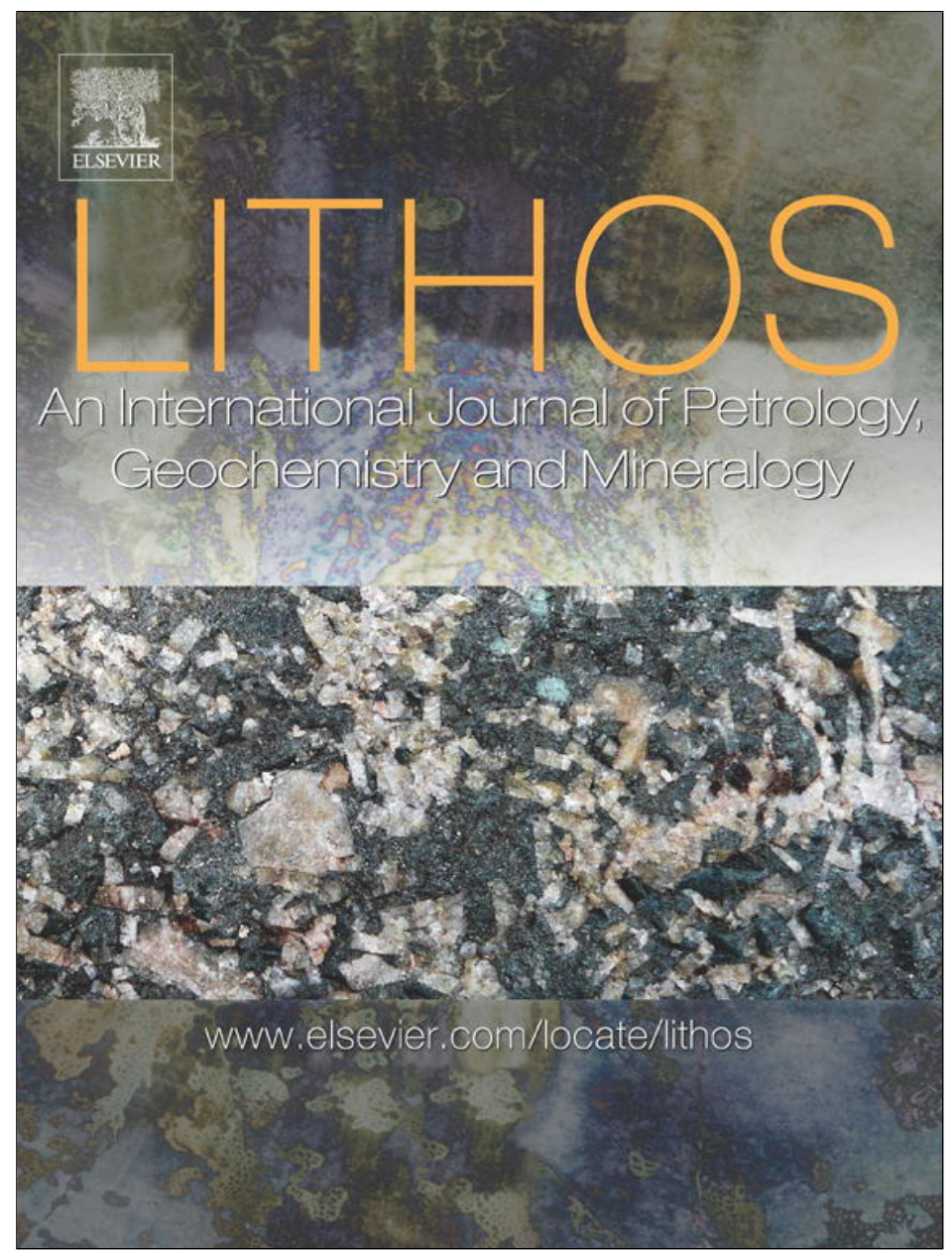

(This is a sample cover image for this issue. The actual cover is not yet available at this time.)

This article appeared in a journal published by Elsevier. The attached copy is furnished to the author for internal non-commercial research and education use, including for instruction at the authors institution and sharing with colleagues.

Other uses, including reproduction and distribution, or selling or licensing copies, or posting to personal, institutional or third party websites are prohibited.

In most cases authors are permitted to post their version of the article (e.g. in Word or Tex form) to their personal website or institutional repository. Authors requiring further information regarding Elsevier's archiving and manuscript policies are encouraged to visit:

http://www.elsevier.com/copyright 


\title{
Timing of eclogite-facies metamorphism of the Chuacús complex, Central Guatemala: Record of Late Cretaceous continental subduction of North America's sialic basement
}

\author{
Uwe C. Martens $^{\mathrm{a}, *}$, Hannes K. Brueckner ${ }^{\mathrm{b}, \mathrm{c}}$, Christopher G. Mattinson ${ }^{\mathrm{a}, 1}$, Juhn G. Liou ${ }^{\text {a }}$, Joseph L. Wooden ${ }^{\mathrm{d}}$ \\ a Department of Geological and Environmental Sciences, Stanford University; Stanford, CA 94305, USA \\ b School of Earth and Environmental Sciences, Queens College and The Graduate Center, CUNY, Flushing, NY 11367, USA \\ c Lamont-Doherty Earth Observatory, Columbia University, Palisades, NY 10964, USA \\ 'd U.S. Geological Survey, 345 Middlefield Road, Menlo Park, CA 94025, USA
}

\section{A R T I C L E I N F O}

\section{Article history:}

Received 20 December 2011

Accepted 16 April 2012

Available online 24 April 2012

\section{Keywords:}

High-pressure metamorphism

Continental subduction

$\mathrm{U}-\mathrm{Pb}$ geochronology

Caribbean-North America plate boundary

Late Cretaceous

\begin{abstract}
A B S T R A C T
A Late Cretaceous collision of the southernmost portion of the North American continental margin with an undetermined southern block was first established based on the sedimentation history of the plate's supracrustal cover, which is overthrust by harzburgite-dominated nappes of the Guatemala Suture Complex. The collision is also well registered in the metamorphic evolution of continental eclogites of the Chuacús complex, a geologic unit that represents Mesoproterozoic-Triassic sialic basement of North America at the boundary with the Caribbean plate. Garnet-clinopyroxene-phengite thermobarometry of eclogites hosted in Chuacús gneisses indicates near ultra-high-pressure conditions to $\sim 700^{\circ} \mathrm{C}$ and $\sim 2.1-2.4 \mathrm{GPa}$. SHRIMP-RG $\mathrm{U}-\mathrm{Pb}$ dating of eclogite metamorphic zircon yielded a $75.5 \pm 2 \mathrm{Ma}$ age ( $95 \%$ confidence level). Chondritenormalized rare-earth element patterns of zircon lack Eu anomalies and show depletions in heavy rare earths, consistent with zircon growing in a plagioclase-free, garnet-rich, eclogite-facies assemblage. Additionally, a Sm-Nd clinopyroxene-two garnet-whole rock isochron from an eclogite band yielded a less precise but consistent age of $77 \pm 13 \mathrm{Ma}$. The above features imply subduction to $>60 \mathrm{~km}$ depth of at least a portion of the North American sialic basement during Late Cretaceous collision.

The Chuacús complex was overprinted by an amphibolite-facies event. For instance, mafic high-pressure paragneiss contains symplectite, resorbed garnet, and amphibole + plagioclase poikiloblasts. Zircon rims from the paragneiss sample show rare-earth patterns consistent with plagioclase growth and garnet breakdown. Their 74.5 \pm 3.5 Ma SHRIMP-RG U-Pb age is therefore interpreted as the time of retrogression, which is consistent with previously published results.

Within error, the ages of the eclogite-facies event and the amphibolite-facies retrogression are equivalent. Thus exhumation of the Chuacús slab from mantle to mid-crustal depth was quick, taking few million years. During exhumation, partial melting of Chuacús gneisses generated ubiquitous pegmatites. One of the pegmatites intruded the North Motagua mélange, which is a serpentinite-rich subduction complex of the Guatemala Suture Complex containing Early Cretaceous oceanic eclogites. $\mathrm{U}-\mathrm{Pb}, \mathrm{Rb}-\mathrm{Sr}$, and $\mathrm{K}-\mathrm{Ar}$ ages of the pegmatite range 76-66 Ma. Thus initial juxtaposition of continental and oceanic high-pressure belts of the Guatemala Suture Complex predates Tertiary-present strike-slip faulting between the North-American and Caribbean plates.
\end{abstract}

(c) 2012 Elsevier B.V. All rights reserved.

\section{Introduction}

The Guatemala Suture Complex (GSC), also known as the Motagua Suture Complex (Giunta et al., 2002; Ratschbacher et al., 2009), is one of the most significant sutures in the Caribbean area (Fig. 1A) because it is composed of not one, but three juxtaposed high-pressure (HP) metamorphic belts (Fig. 1B): the Chuacús complex, the North

\footnotetext{
* Corresponding author at: Tectonic Analysis Inc., 1315 Alma Ave Ste 134, Walnut Creek, CA 94596, USA. Tel.: +1 6508044061.

E-mail address: umartens@zoho.com (U.C. Martens).

1 Present address: Department of Geological Sciences, Central Washington University, Ellensburg, WA 98926-7418, USA.
}

Motagua, and the South Motagua serpentinite mélanges. These belts record diachronous events involving subduction, collision, and exhumation of both oceanic and continental crust (e.g., Brueckner et al., 2009; Harlow et al., 2004; Ortega-Gutiérrez et al., 2004; Tsujimori et al., 2004, 2006). Establishing the metamorphic ages of the highpressure belts and the timing of their juxtaposition within the GSC is critical to unraveling the complex evolution of the Caribbean-North America plate boundary.

Important additional constraints on the evolution of this plate boundary are provided by the Cretaceous passive margin succession (e.g., Cobán Formation) included in the sedimentary crustal cover of the southernmost portion of the North American plate (locally known as the Maya Block; Fig. 1C). Shallow-level passive-margin 


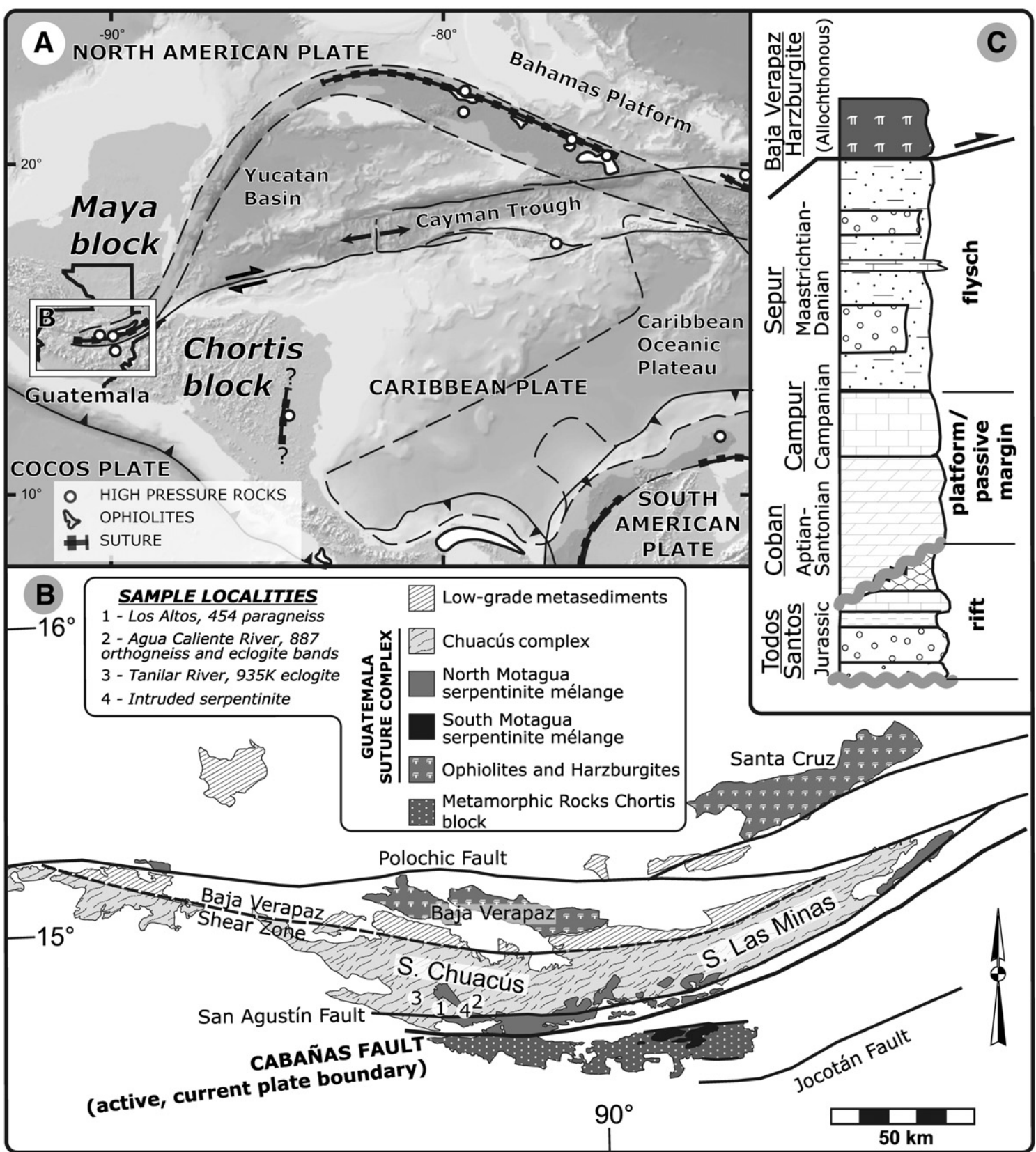

Fig. 1. (A) Tectonic map of the northern Caribbean showing the location of ophiolites, sutures, and high-pressure rocks; notice the location of the Guatemala Suture Complex; (B) simplified geologic map of Central Guatemala modified from Bonis et al. (1970) and Bonis (1993) showing location of samples; (C) simplified Mesozoic stratigraphic column of north-central Guatemala modified from Michaud et al. (1992) and Fourcade et al. (1994, 1999).

beds are overlain by strata containing fauna indicating a slope and basin environment beneath the photic zone, and recording the onset of subsidence and deepening of the platform (Campur Formation; Fourcade et al., 1994, 1999; Vinson, 1962). The age of this deepening event is constrained by the globally occurring Globotruncana calcarato zone (Fourcade et al., 1994; Puckett and Mancini, 1998), dated at $\sim 73 \mathrm{Ma}$ (uppermost Campanian) by $\mathrm{Sr}$ isotopic values of foraminiferal calcite (Neuhuber and Wagreich, 2008). These Campanian beds are in turn overlain by the Sepur Formation (Sapper, 1899), a MaastrichtianDanian turbidite fan succession (Fourcade et al., 1994, 1999; Rosenfeld, 1981). This turbidite fan system is the youngest unit involved in deformation related to the northward emplacement of harzburgitedominated nappes (i.e., the Sierra de Santa Cruz and Baja Verapaz ophiolites in Fig. 1B; Beccaluva et al., 1995; Rosenfeld, 1981; Wilson, 1974).
The above features are evidence for the creation and deformaton of a foredeep sequence during a Late Cretaceous collision of the southern edge of the North American plate with either the Great Antilles Arc, the Nicaragua Rise, or the Chortís Block (for current reviews see: Brueckner et al., 2009; García-Casco et al., 2008; Ortega-Obregón et al., 2008; Pindell and Kennan, 2009; Ratschbacher et al., 2009). The collision involved basement rocks of the southern Maya Block which were metamorphosed under greenschist- and amphibolite-facies (Chuacús Complex) and developed structures characteristic of sinistral transpression (Ratschbacher et al., 2009). However, important questions remained regarding the age and significance of eclogites within the continental basement rocks, and the relations between the continental and oceanic highpressure belts of the GSC.

We present pressure and temperature estimates, SHRIMP-RG U-Pb ages and trace element geochemistry of zircon, and a Sm-Nd mineral 
isochron age for continental eclogites that occur within the crystalline rocks of the Chuacús complex exposed in the southern flank of the Sierra de Chuacús. We demonstrate that there was continental subduction of a portion of the southernmost edge of the North American continent during the Campanian and link this collisional event with the abrupt subsidence and deformation recorded in sedimentary rocks north of the suture zone. We also present a model for initial juxtaposition of the Chuacús complex and the North Motagua serpentinite mélange of the GSC.

\section{Geologic Setting}

The present-day North America-Caribbean plate boundary is a left-lateral transform/strike-slip system that extends from western Guatemala to the active Antilles Arc (Fig. 1A-B). The transform system has an accumulated sinistral displacement of $>1100 \mathrm{~km}$, well constrained by the width of new ocean crust generated along the Cayman trough spreading center (e.g., Rosencrantz and Mann, 1991; Rosencrantz and Sclater, 1986). Displacement along the western portion of the boundary has been mainly accommodated by the Motagua Fault system (Fig. 1B). This fault system includes a series of arcuate, nearly parallel, E-W trending fault zones, whose relative contributions to the overall sinistral displacement between the North America and Caribbean plates are poorly known (e.g., Schwartz et al., 1979). The presently active strand of the Motagua Fault system is the Cabañas fault (Fig. 1B; Plafker, 1976), which therefore represents the current plate boundary.

It has long been recognized that the Cabañas fault juxtaposes two disparate continental blocks known as Maya block (to the north) and Chortís blocks (to the south; Dengo, 1969). The Maya block represents the southernmost part of the North American plate and the Chortís Block represents the continental portion of the otherwise largely oceanic Caribbean plate (Fig. 1A). However, the boundary between these two blocks is more complicated than a single strike slip fault. The region from the Polochic to the Jocotán valleys is characterized by a number of $\sim \mathrm{E}-\mathrm{W}$ faults and shear zones, and by a complex array of faulted slivers of serpentinite, serpentinite mélange, metasedimentary mélange, ophiolites, perhaps pieces of island arcs, mantle harzburgite, and continental gneisses that have recently been shown to contain eclogites (Ortega-Gutiérrez et al., 2004). We refer to this array of geologic units as the Guatemala Suture Complex (GSC).

\subsection{High-pressure belts of the GSC and the Chuacús complex}

Three belts containing high-pressure rocks have been recognized in the GSC. South of the Cabañas fault, the GSC is characterized by a serpentinite mélange containing various types of exotic blocks including blueschist and lawsonite eclogite. These lawsonite eclogites underwent peak metamorphic conditions at $\sim 480-520^{\circ} \mathrm{C}$ and $\sim 2.5-$ 2.6 GPa (Endo et al., 2012; Tsujimori et al., 2006). Adjacent to but north of the Cabañas fault, a second belt of serpentinite mélange distinctively contains blocks of garnet amphibolite (with relic omphacite), jadeitite, epidote eclogite, and blueschist. The northern eclogites record conditions at $\sim 600-650{ }^{\circ} \mathrm{C}$ and $\sim 2 \mathrm{GPa}$, and were overprinted by an epidote-amphibolite assemblage (Tsujimori et al., 2004). Sm-Nd mineral isochrons of eclogites from both the southern and northern mélanges yielded equivalent 144-126 Ma ages (Brueckner et al., 2009). The age, thermobarometry, and oceanic nature of the rocks involved indicate eclogite-facies metamorphism occurred during oceanic subduction, and we interpret both eclogite-bearing belts as having formed at a single subduction zone (Brueckner et al., 2009). In contrast, ${ }^{40} \mathrm{Ar} /{ }^{39} \mathrm{Ar}$ cooling ages are significantly different for the two mélanges indicating either that they formed in separate subduction zones (e.g., Ratschbacher et al., 2009) or that they underwent different exhumation and overprinting histories. White mica from blocks contained in the southern mélange yielded 125-113 Ma ages, while white mica and amphibole from blocks in the northern serpentinite mélange yielded ages $<77 \mathrm{Ma}$, which represent cooling after a later amphibolite-facies recrystallization event (Harlow et al., 2004; Sutter, 1979).

Ortega-Gutierrrez et al. (2004) recognized that eclogites in the GSC were not only hosted in serpentinites but also occurred as bands and boudins in the high-grade granitic gneisses of the Chuacús complex, to the north of the Cabañas Fault (Fig. 1). Field work revealed that minor eclogites occur in a $40 \times 20 \mathrm{~km}$ area in the southern flank of the Sierra de Chuacús (Ortega-Gutiérrez et al., 2004; plate 1 in Martens, 2009), where the Chuacús complex is chiefly composed of granitegranodiorite-diorite orthogneisses, kyanite + garnet metapelites, twomica gneisses, amphibolites, and marbles. Four analyses of orthogneiss yielded calc-alkaline chemistry with arc signature, and six analyses of amphibolite/eclogite yielded tholeiitic signature, similar to mid-ocean ridge basalt (Solari et al., 2011). Available thermobarometric calculations of Chuacús eclogites indicate conditions within the $\mathrm{T} \sim 575-750{ }^{\circ} \mathrm{C}$ and $\mathrm{P}$ 2-2.3 GPa range (Ortega-Gutiérrez et al., 2004; Ratschbacher et al., 2009). This contrasts with the bulk of the metamorphic unit in the Sierra de Chuacús, which contains amphibolite-facies assemblages (van den Boom, 1972) equilibrated at $\mathrm{T} \sim 475-575{ }^{\circ} \mathrm{C}$ and $\mathrm{P} \sim 0.6-0.9 \mathrm{GPa}$ (Ratschbacher et al., 2009). Chuacús U-Pb zircon rim ages, and $\mathrm{Rb}-\mathrm{Sr}$ and ${ }^{40} \mathrm{Ar} /{ }^{39} \mathrm{Ar}$ cooling ages of foliation-forming white mica and amphibole yielded ages in the 76-62 Ma range (Ratschbacher et al., 2009, and references therein). These ages have been interpreted to reflect the time of the epidote-amphibolite metamorphism.

Another important feature of the Chuacús complex is the ubiquitous presence of pegmatites. Although some are foliated or folded (e.g., in El Chol), most pegmatites are massive or weakly deformed bodies a few decimeters to several tens of meters in length (Fig. 2). They are Al- and K-rich granites composed of two feldspars, abundant white mica, quartz and minor tourmaline. Most of these massive to slightly foliated pegmatites truncate the dominant foliation of Chuacús gneisses, although some intrude fold hinges or were injected parallel to the dominant foliation. Based on $\mathrm{Ar}-\mathrm{Ar}$ and $\mathrm{Rb}-\mathrm{Sr}$ ages of micas from orthogneisses and paragneisses, Ratschbacher et al. (2009) concluded that the dominant foliation developed during the late Cretaceous (Ratschbacher et al., 2009). We therefore interpret the group of unfoliated pegmatites as late- to post-tectonic intrusions.

Field characteristics suggest that the intrusions were generated by partial melts from within the Chuacús gneisses (van den Boom, 1972). For instance, migmatitic gneisses at Agua Caliente contain decimeter-scale pegmatite pockets that partially truncate and partially wrap around the foliation. These are connected to each other by pegmatite bands a few centimeters thick (Fig. 2A-B). These bands are also connected to larger, meter-sized intrusive pegmatites (Fig. 2C). We interpret the pockets as in-situ melts of Chuacús gneisses, and the centimeter-scale bands as feeders to larger pegmatite bodies. The $\mathrm{U}-\mathrm{Pb}$ age of zircon rims from a pegmatite that intruded a neck between boudins yielded $\sim 74 \mathrm{Ma}$, which was interpreted to record crystallization under high-grade metamorphic conditions (Solari et al., 2011).

One of the larger undeformed pegmatites of the Sierra de Chuacús is particularly important because it intrudes a large body of antigorite schist of the North Motagua mélange. The intrusion can be followed for several tens of meters and it is characterized by meter-sized ultramafic xenoliths and by phlogopite and fuchsite at the contact. Otherwise, the size, mineral content, and texture of the pegmatite are indistinguishable from similar intrusions in the Chuacús complex. $\mathrm{K}$-Ar ages of larger ( $>300 \mu \mathrm{m})$ muscovite and fuchsite grains from this pegmatite range $76-69.0 \pm 1.0 \mathrm{Ma}$ (Ortega-Gutiérrez et al., 2004) and a $\mathrm{Rb}-\mathrm{Sr}$ whole rock + white mica isochron yielded an age of $67 \pm 11$ Ma (Ratschbacher et al., 2009). These cooling ages are equivalent to those obtained in Chuacús gneisses and in exotic blocks of the North Motagua mélange (Harlow et al., 2004; Ratschbacher et al., 2009). 

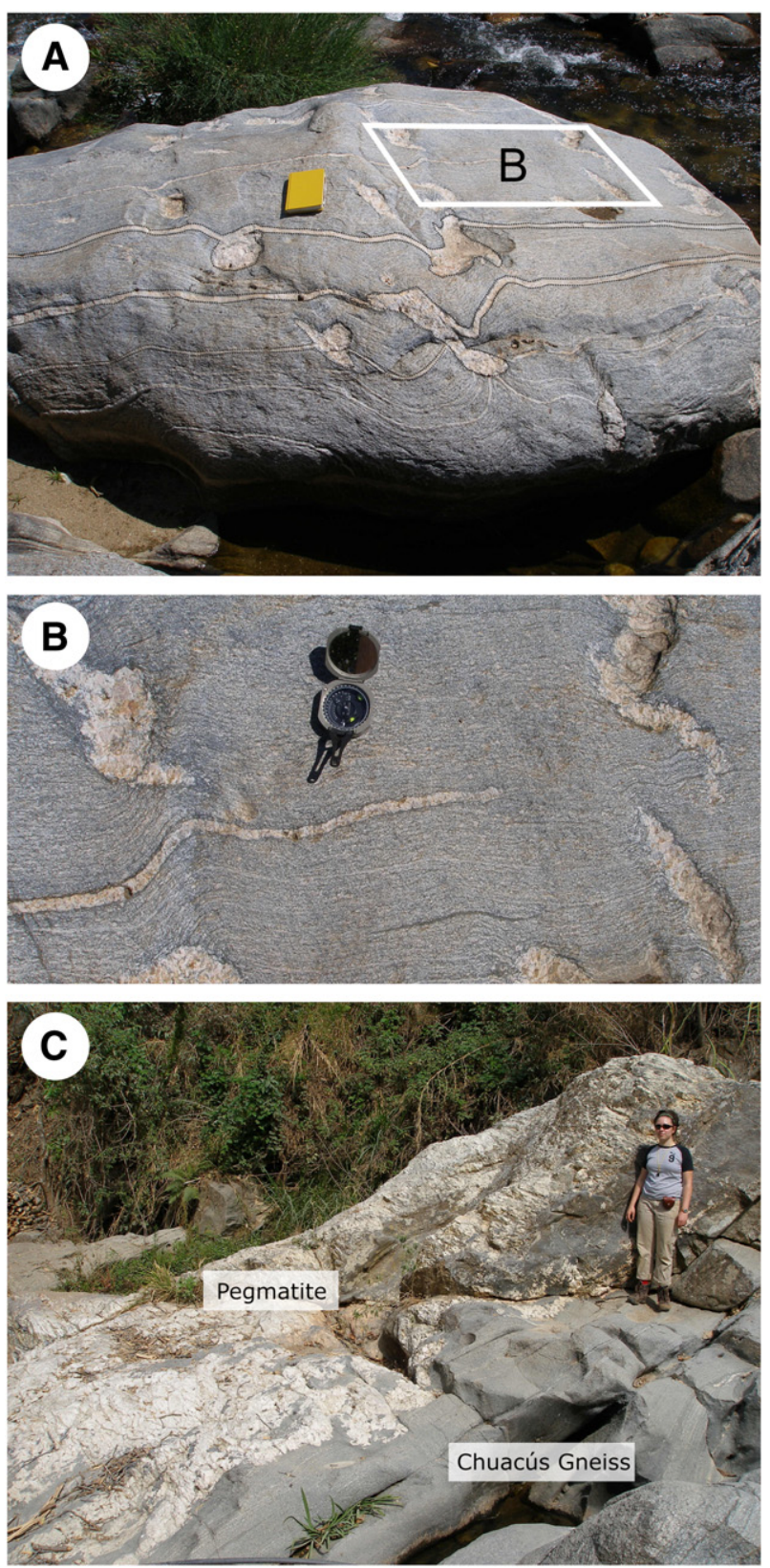

Fig. 2. Field photographs of $(A)$ pegmatite pockets in Chuacús orthogneisses that host eclogite (not shown) at the Agua Caliente locality; outline in white corresponds to detail shown in (B); (C) pegmatite intrusion in Chuacús gneisses at Tanilar River.

\section{Analytical procedures}

\subsection{Thermobarometry}

Mineral chemistry was determined using the JEOL 733A electron microprobe at Stanford University with operating conditions of $15 \mathrm{nA}$ beam current and $15 \mathrm{keV}$ accelerating potential, and calibrated on natural mineral standards. Raw counts of $\mathrm{Si}, \mathrm{Al}, \mathrm{Fe}, \mathrm{Mg}, \mathrm{Mn}, \mathrm{K}, \mathrm{Na}$, $\mathrm{Ca}, \mathrm{Cr}$, and Ti were collected for $20 \mathrm{~s}$ and converted to wt\% by the CITZAF correction procedure. Minerals were analyzed with a focused beam $(<2 \mu \mathrm{m})$. Representative mineral compositions of Grt, Omp, and Phg are listed in Table 1 (mineral abbreviations from Siivola and Schmid, 2007).

The garnet-clinopyroxene-phengite thermobarometer was applied using the Excel® spreadsheet by E. Krogh-Ravna. The spreadsheet uses the calibration of Krogh-Ravna and Terry (2004), activity model for phengite solid solution of Holland and Powell (1998), the
Table 1

Representative electron probe analyses of minerals used for thermobarometry.

\begin{tabular}{|c|c|c|c|c|c|c|c|c|}
\hline \multirow[t]{2}{*}{ wt\% } & \multicolumn{2}{|l|}{$\mathrm{Cpx}$} & \multicolumn{3}{|c|}{ Garnet } & \multicolumn{3}{|c|}{ Phengite } \\
\hline & $887 a$ & $887 \mathrm{~b}$ & & $887 a$ & $887 \mathrm{~b}$ & & $887 a$ & $887 b$ \\
\hline $\mathrm{SiO}_{2}$ & 53.5 & 54.9 & & 37.9 & 38.2 & & 47.2 & 47.5 \\
\hline $\mathrm{TiO}_{2}$ & 0.167 & 0.079 & & b.d. & 0.073 & & 1.161 & 1.14 \\
\hline $\mathrm{Al}_{2} \mathrm{O}_{3}$ & 7.554 & 7.879 & & 21.1 & 21.2 & & 27.2 & 27.1 \\
\hline $\mathrm{FeO}^{\mathrm{a}}$ & 9.738 & 9.60 & & 24.9 & 24.1 & & 4.774 & 4.79 \\
\hline $\mathrm{MnO}$ & 0.076 & 0.014 & & 2.155 & 2.832 & & b.d. & b.d. \\
\hline $\mathrm{MgO}$ & 7.609 & 7.757 & & 2.691 & 2.456 & & 2.417 & 2.57 \\
\hline $\mathrm{CaO}$ & 15.0 & 14.6 & & 10.4 & 11.0 & & b.d. & b.d. \\
\hline $\mathrm{Na}_{2} \mathrm{O}$ & 5.43 & 5.381 & & b.d. & b.d. & & 0.429 & 0.46 \\
\hline $\mathrm{K}_{2} \mathrm{O}$ & b.d. & b.d. & & b.d. & b.d. & & 10.5 & 10.5 \\
\hline \multirow[t]{3}{*}{ Tot. } & 99.0 & 100.2 & & 99.2 & 99.8 & & 93.7 & 94.0 \\
\hline & \multirow{2}{*}{\multicolumn{3}{|c|}{$\begin{array}{l}\text { Cations per } \\
6 \text { oxygen }\end{array}$}} & \multirow{2}{*}{\multicolumn{3}{|c|}{$\begin{array}{l}\text { Cations per } \\
12 \text { oxygen }\end{array}$}} & \multirow{2}{*}{\multicolumn{2}{|c|}{$\begin{array}{l}\text { Cations per } \\
11 \text { oxygen }\end{array}$}} \\
\hline & & & & & & & & \\
\hline $\mathrm{Si}$ & 1.98 & 2.00 & $\mathrm{Si}$ & 3.00 & 3.00 & $\mathrm{Si}$ & 3.27 & 3.34 \\
\hline $\mathrm{Al}$ & 0.02 & 0.00 & & & & $\mathrm{Al}$ & 0.73 & 0.66 \\
\hline $\mathrm{T}$ & 2.00 & 2.00 & $\mathrm{~T}$ & 3.00 & 3.00 & $\mathrm{~T}$ & 4.00 & 4.00 \\
\hline $\mathrm{Al}$ & 0.31 & 0.34 & $\mathrm{Si}$ & 0.02 & 0.02 & $\mathrm{Ti}$ & 0.06 & 0.02 \\
\hline $\mathrm{Fe}^{+3}$ & 0.06 & 0.04 & $\mathrm{Al}$ & 1.98 & 1.97 & $\mathrm{Al}$ & 1.48 & 1.57 \\
\hline $\mathrm{Ti}$ & 0.00 & 0.00 & & & & $\mathrm{Fe}^{+2}$ & 0.28 & 0.13 \\
\hline $\mathrm{Mg}$ & 0.42 & 0.42 & & & & $\mathrm{Cr}$ & 0.00 & 0.00 \\
\hline $\mathrm{Fe}^{+2}$ & 0.21 & 0.20 & & & & $\mathrm{Mg}$ & 0.25 & 0.33 \\
\hline M1 & 1.00 & 1.00 & $\mathrm{Y}$ & 2.00 & 1.991 & 0 & 2.07 & 2.05 \\
\hline $\mathrm{Fe}^{+2}$ & 0.02 & 0.05 & $\mathrm{Fe}^{+2}$ & 1.655 & 1.595 & $\mathrm{Ca}$ & 0.00 & 0.00 \\
\hline $\mathrm{Ca}$ & 0.59 & 0.57 & $\mathrm{Mn}$ & 0.145 & 0.189 & $\mathrm{Na}$ & 0.06 & 0.11 \\
\hline $\mathrm{Na}$ & 0.39 & 0.38 & $\mathrm{Mg}$ & 0.319 & 0.289 & $\mathrm{~K}$ & 0.93 & 0.85 \\
\hline $\mathrm{Mn}$ & 0.00 & 0.00 & $\mathrm{Ca}$ & 0.888 & 0.93 & & & \\
\hline M2 & 1.00 & 1.00 & $X$ & 3.01 & 3.00 & It & 0.99 & 0.96 \\
\hline
\end{tabular}

b.d. = below detection limit.

$\mathrm{T}=$ tetrahedral site; $\mathrm{O}=$ octahedral site; $\mathrm{It}=$ inter-layer site.

$\mathrm{M} 1$ and $\mathrm{M} 2$ octahedral sites in $\mathrm{CpX}$.

$\mathrm{X}$ and $\mathrm{Y}$ sites of $\mathrm{X}_{3} \mathrm{Y}_{2}\left(\mathrm{SiO}_{4}\right)_{3}$ pyraslpite garnets.

a Total Fe reported as $\mathrm{FeO}$.

clinopyroxene activity model of Holland (1990), and the garnet activity model of Ganguly et al. (1996). As suggested by Carswell et al. (2000), compositions selected to calculate peak pressure were Grt with maximum $X_{\mathrm{Grs}}^{2}{ }^{*} X_{\mathrm{Pyp}}$, Omp with maximum $X_{\mathrm{Jd}}$, and Phg with maximum Si per formula unit.

\subsection{U-Pb SHRIMP RG zircon geochronology and trace elements}

High-purity mineral separates were obtained using standard mineral-separation techniques, including crushing, grinding, magnetic separation, and heavy liquids. Zircons were extracted from the nonmagnetic fraction at $2 \mathrm{~A}$ with $10^{\circ}$ side slope and sank in MEI with a density of $\sim 3.3 \mathrm{~g} / \mathrm{cc}$. Zircons were mounted on $1^{\prime \prime}$ disks, exposed to approximate half-sections, and imaged using reflected light and cathodoluminescence. Zircons were coated with Au and analyzed relative to standard R33 (419 Ma age; Black et al., 2004) using the Stanford/USGS SHRIMP-RG facility. Analyses were performed using $\sim 5 \mathrm{nA} \mathrm{O2-primary}$ beam focused to $\sim 30 \mu \mathrm{m}$, and the mass resolution was set to $\sim 7000$ 8000 at $10 \%$ peak height. Data were reduced using the programs Squid and Isoplot (Ludwig, 2001, 2003). Concentration data for U, Th, and trace elements (Tables 1-2 of online supplementary data) were standardized against MAD-green zircon (4200 ppm U). For zircon traceelement analyses, an isotope representing each element was selected, based on its relative abundance and absence of significant interferences at the particular mass, similar to Mattinson et al. (2006). Peaks at ${ }^{139} \mathrm{La}$, ${ }^{140} \mathrm{Ce},{ }^{146} \mathrm{Nd},{ }^{148} \mathrm{Sm},{ }^{153} \mathrm{Eu},{ }^{157} \mathrm{Gd},{ }^{163} \mathrm{Dy},{ }^{166} \mathrm{Er}^{16} \mathrm{O},{ }^{172} \mathrm{Yb}^{16} \mathrm{O}$ were counted for $2 \mathrm{~s}$ and normalized to ${ }^{96} \mathrm{Zr}$.

\subsection{Sm-Nd analytical technique}

Pure mineral separates of Cpx, Grt, Am were obtained through magnetic separation and laborious hand picking on a binocular 
Table 2

Coordinates of sample locations. Coordinate system is UTM Zone 15, WGS84.

\begin{tabular}{llll}
\hline Sample & Site description & $X$ coordinate & $Y$ coordinate \\
\hline 454 & Unpaved road Pachalum-Los Altos & 754,831 & 1 1'650,400 \\
887 & $\begin{array}{l}\text { Agua Caliente river, 200 m upstream } \\
\text { from bridge on road El Chol-Granados }\end{array}$ & 768,630 & $1^{\prime} 652,720$ \\
935 & Río Tanilar, outcrop under bridge & 744,812 & 1 1'656,252 \\
\hline
\end{tabular}

microscope. The mineral separates and an aliquot of whole rock powder were leached in hot, concentrated $\mathrm{HNO}_{3}$ and $\mathrm{HCl}$ solutions and a cold, dilute HF solution. The samples were spiked with ${ }^{150} \mathrm{Nd}$ and ${ }^{152} \mathrm{Sm}$, dissolved in 8:1 $\mathrm{HF}: \mathrm{HClO}_{4}$, and $\mathrm{Nd}$ and $\mathrm{Sm}$ were separated using TRU-SPEC and Alpha-Hiba resins and solutions. Isotopes were analyzed on a VG 54-30 mass spectrometer at Lamont-Doherty Earth Observatory of Columbia University. Procedural blanks for Nd are $30-140 \mathrm{pg}$. Repeated runs of standards gave an average ${ }^{143} \mathrm{Nd} /{ }^{144} \mathrm{Nd}$ ratio of $0.511857 \pm 42$ for the La Jolla Nd standard $(2 \sigma$, standard deviation, $n=20$ ) at the time the samples were being analyzed. The ${ }^{143} \mathrm{Nd} /{ }^{144} \mathrm{Nd} \mathrm{ra-}$ tios were corrected for machine fractionation by normalizing to ${ }^{146} \mathrm{Nd} /$ ${ }^{144} \mathrm{Nd}$ of 0.72190 . Sm-Nd isochrons were calculated using the Isoplot/Ex 3 program (Ludwig, 2003). ${ }^{147} \mathrm{Sm} /{ }^{144} \mathrm{Nd}$ errors are taken to be $0.3 \%$. The errors in ${ }^{143} \mathrm{Nd} /{ }^{144} \mathrm{Nd}$ were estimated using the relationship $\left(X^{2}+Y^{2}\right)^{1 / 2}$ where $X$ is the standard deviation of the mean $(0.000021,2 \sigma)$ of replicate standard analyses $(n=20)$ and $Y$ is the standard deviation of the mean $(2 \sigma)$ of each individual run.

\section{Sample description, thermobarometry, and geochronology}

Samples of eclogites and host gneisses from the Chuacús complex were collected for geothermobarometry and geochronology (Fig. 1; coordinates of sample locations in Table 2). Eclogite sample $935 \mathrm{~K}$ was collected at Tanilar River and it yielded zircons with metamorphic rims sufficiently thick and containing enough $U$ for precise U-Pb SHRIMPRG dating and REE analyses (Tables 1-2 of online supplementary data). Samples $887 \mathrm{a}$ and $887 \mathrm{~b}$ are from a $1.5 \mathrm{~m}$-thick eclogite layer in orthogneiss in Agua Caliente River. They were processed for Grt-OmpPhg thermobarometry and Sm-Nd mineral isochron dating (Table 3). Sample 887c is orthogneiss collected a few centimeters from gneisseclogite contact, and sample 454 is quartz-rich, banded gneiss containing omphacite + garnet. Both were collected for zircon REE analyses and U-Pb SHRIMP-RG geochronology.

\subsection{Tanilar eclogite, sample $935 \mathrm{~K}$}

The sample from the Tanilar River is a fine-grained granoblastic eclogite containing the HP paragenesis Omp $+\mathrm{Grt}+\mathrm{Rt}+$ minor Zo. Zircon is a common accessory, occurring in the matrix and as inclusion in both omphacite and garnet. Slight retrogression produced centimeter-scale poikiloblastic albite and amphibole, which locally consume omphacite and the outer parts of garnet. Separated zircons are $75-150 \mu \mathrm{m}$, and their cathodoluminescence (CL) reveals cores with oscillatory zoning and rims that are featureless or sector zoned

Table 3

$\mathrm{Sm} / \mathrm{Nd}$ isotopic data, Chuacús 887 eclogite.

\begin{tabular}{llllll}
\hline Sample & $\mathrm{Sm}(\mathrm{ppm})$ & $\mathrm{Nd}(\mathrm{ppm})$ & ${ }^{147} \mathrm{Sm} /{ }^{144} \mathrm{Nd}$ & ${ }^{143} \mathrm{Nd} /{ }^{144} \mathrm{Nd}$ & $2 \sigma$ \\
\hline 887b CPx & 1.025 & 4.052 & 0.1529 & 0.513018 & 0.000010 \\
887b Grt 1 & 0.509 & 0.665 & 0.4629 & 0.513167 & 0.000010 \\
887b Grt 2 & 0.482 & 0.648 & 0.4493 & 0.513165 & 0.000009 \\
887b Hbl & 0.955 & 3.423 & 0.1687 & 0.513015 & 0.000010 \\
887b Whole rock & 1.270 & 4.047 & 0.1898 & 0.513034 & 0.000012 \\
\hline
\end{tabular}

and that truncate the core's texture (Fig. 3A). Seven zircon cores yielded ages in the 265-215 Ma range with a weighted mean of $227 \pm$ $19 \mathrm{Ma}$ (unless indicated otherwise, all ages were calculated from ${ }^{206} \mathrm{~Pb} /{ }^{238} \mathrm{U}$ and were corrected for common $\mathrm{Pb}$ by assuming ${ }^{206} \mathrm{~Pb} /$ ${ }^{238} \mathrm{U}-{ }^{207} \mathrm{~Pb} /{ }^{235} \mathrm{U}$ age-concordance; mean ages reported at $95 \%$ confidence level; Fig. 4). This age is interpreted as the time of crystallization of the mafic igneous protolith of the eclogite.

Sixteen analyses of rims yielded 6-26 ppm $U$ and $\mathrm{Th} / \mathrm{U}=0.01-0.07$, some of which contained appreciable common $\mathrm{Pb}$. A regression line (York, 1969) through uncorrected isotopic ratios of rims, excluding the one with highest common $\mathrm{Pb}$, yielded an intercept age of $75.5 \pm 1.9 \mathrm{Ma}$ (Fig. 4A). The mean age of zircon rims uncontaminated by common $\mathrm{Pb}$ (concordant on Tera-Wasserburg diagram of uncorrected isotopic ratios) yielded an age of $75.2 \pm 2.2 \mathrm{Ma}$. The chondrite-normalized REE pattern of zircon rims does not show a prominent Eu anomaly and is significantly depleted in the HREE (Fig. 5), consistent with zircon growth or recrystallization within a paragenesis including garnet and excluding plagioclase. Therefore, the Campanian age can reasonably be assigned to the eclogite-facies event.

\subsection{Agua Caliente eclogites, samples $887 a$ and $887 b$}

Samples 887 a and $887 \mathrm{~b}$ are eclogites partially overprinted by an amphibolite-facies assemblage. The eclogite-facies minerals in both samples are Omp $+\mathrm{Grt}+\mathrm{Phg}+\mathrm{Rt}+\mathrm{Zo}$. Garnet occurs as subhedral to anhedral grains with diameter $<0.5 \mathrm{~mm}$. Some of the pyroxene crystals have edges of blue-green amphibole. Rutile is commonly rimmed by titanite. Retrogression also generated $>1 \mathrm{~cm}$ poikiloblasts of albite and amphibole that are randomly oriented and enclose mineral relics of the eclogite-facies assemblage. In contrast, symplectites of clinopyroxene and plagioclase are not widely developed. Cpx varies from Omp $=\mathrm{Jd}_{36} \mathrm{Di} / \mathrm{Hd}_{60} \mathrm{Aeg}_{4-10}$ in peak eclogitic domains to $\mathrm{Jd}_{8} \mathrm{Di} /$ $\mathrm{Hd}_{83} \mathrm{Aeg}_{6-11}$ in the retrograded symplectite $\left(\mathrm{Fe}^{+3}\right.$ calculated assuming 4 cations and 6 oxygens; Table 1). Garnet is relatively unzoned with compositions near $\mathrm{Alm}_{0.50-0.55} \operatorname{Prp}_{0.12-0.16} \mathrm{Grs}_{0.27-0.35} \mathrm{Sps}_{0.04-0.08}$. Phengite contains up to $3.3 \mathrm{Si}$ atoms p.f.u. (11 oxygen basis). Based on these analyses, the Grt-Omp-Phg thermobarometer yielded eclogitefacies conditions of $660-750{ }^{\circ} \mathrm{C}$ and $21-24 \mathrm{kbar}$, near the coesite stability field (see Section 3.2 for calibration and activity models used). These estimates give a range of conditions that is in agreement to previous calculations by Ortega-Gutiérrez et al. (2004) and Ratschbacher et al. (2009). The scatter in T and P estimations is unlikely a natural feature but possibly a consequence of using the relatively unreliable garnetomphacite $\mathrm{Fe}^{+2}-\mathrm{Mg}$ exchange thermometer (Proyer et al., 2004). However in the absence of kyanite, this thermometer provides the most adequate temperature constraint for eclogites (Krogh-Ravna and Terry, 2004).

Very pure Grt, Omp, and Am mineral separates and an aliquot of powdered whole rock were analyzed for $\mathrm{Sm}$ and $\mathrm{Nd}$ isotopes (Fig. 6). An isochron calculation using all four phases, with garnet analyzed twice, yielded a $77 \pm 13 \mathrm{Ma}$ age. Inasmuch as amphibole is part of the retrogression assemblage, a second isochron excluding this mineral was calculated. The result is not significantly different, $75 \pm 14 \mathrm{Ma}$. This suggests that the retrogression amphibole grew quickly after the eclogite-facies assemblage or inherited the isotopic signature from the eclogitic minerals, most likely from the Cpx. The age is relatively imprecise ( $\sim 17 \%$ error), largely due to the lack of dispersion along the ${ }^{147} \mathrm{Sm} /{ }^{144} \mathrm{Nd}$ axis between Omp and Grt and an estimated analysis error that was calculated based on longterm replicates of $\mathrm{Nd}$ standards. If the precision of each run is used as the calculated error, the age becomes a much more precise $77.0 \pm 4.7 \mathrm{Ma}$ using all phases $(\mathrm{MSWD}=1.03$ ) and $75.1 \pm 5.3 \mathrm{Ma}$ excluding amphibole (MSWD $=0.28$ ). Regardless of the combinations and errors used, the Sm-Nd mineral isochron results are identical, within error, to the SHRIMP-RG U-Pb age of the eclogite-facies event (sample $935 \mathrm{~K}$ ). 

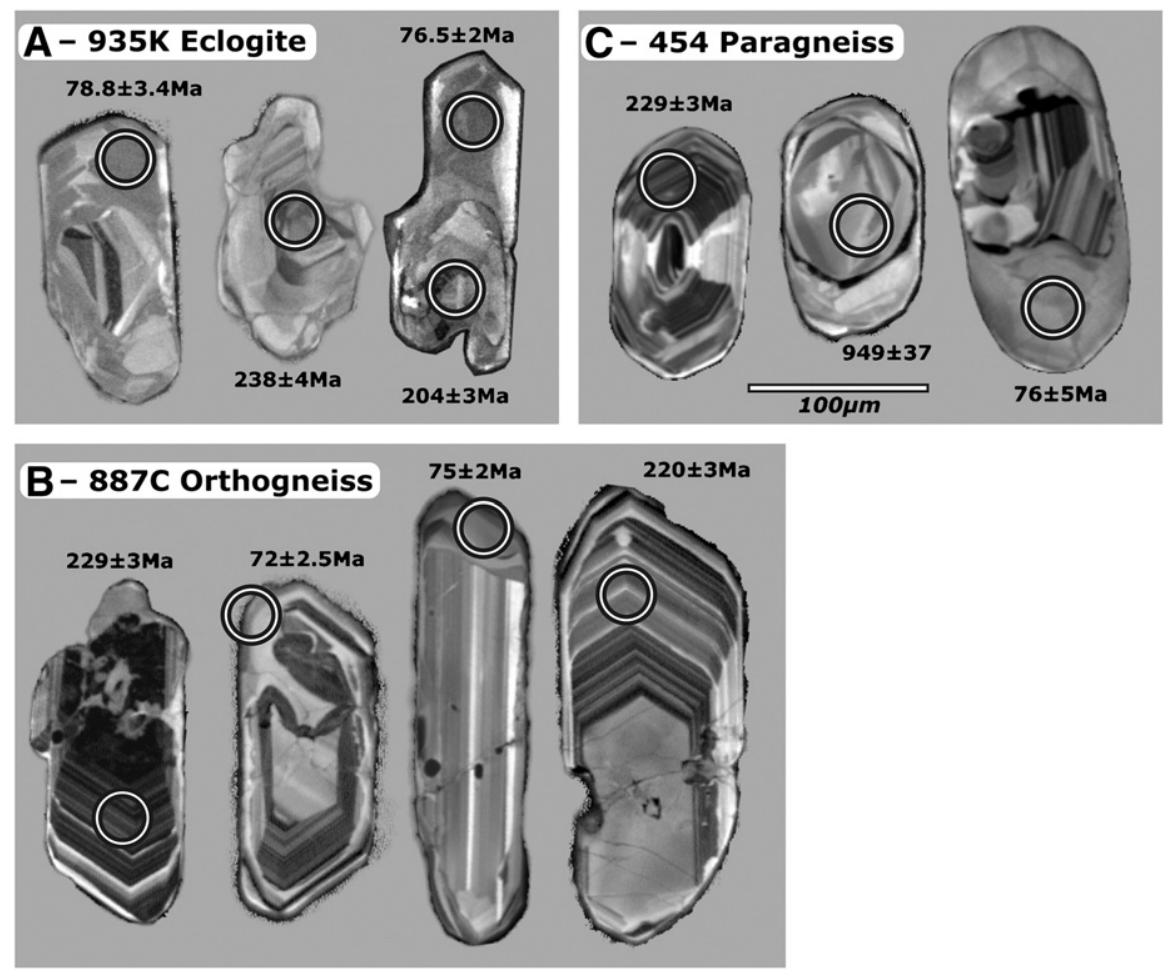

Fig. 3. CL images of zircons used for SHRIMP RG geochronology showing examples of core-rim relations. Circles indicate the position of analyses; ${ }^{238} \mathrm{U} /{ }^{206} \mathrm{~Pb}$ ages are given.

\subsection{Agua Caliente host orthogneiss, sample 887c}

Gneiss 887c contains Qtz + Afs (microcline) + albite/oligoclase + $\mathrm{Wmca}+\mathrm{Bt}+\mathrm{Ep}$ (allanite cores) + minor Grt, Ttn and accessory Zrn. In the field, primary intrusive contacts of this gneiss into $\mathrm{Bt}+\mathrm{Grt}$ gneiss are partially preserved. Zircon CL shows cores with oscillatory zoning (Fig. 3B). Eight analyses of the oscillatory-zoned interiors yielded a mean $\mathrm{U}-\mathrm{Pb}$ age of $223 \pm 4 \mathrm{Ma}$ (Fig. 4B). The chondritenormalized REE patterns of zircon cores (Fig. 5) contain prominent negative Eu anomalies and enrichment in HREE's, consistent with a magmatic zircon origin co-genetic with feldspar, but without the presence of garnet. The Triassic age is interpreted as the igneous event that formed the granitic protolith of the orthogneiss, consistent with previous results of Ratschbacher et al. (2009).

In $\mathrm{CL}$, many of the zircons also show featureless light-gray rims that truncate the cores. Four analyses of rims yielded $\sim 50-177 \mathrm{ppm}$ $\mathrm{U}$, low $\mathrm{Th} / \mathrm{U}=0.01-0.03$, and appreciable common $\mathrm{Pb}$. A regression line through the uncorrected isotopic ratios (York, 1969) yielded an intercept age of $74.4 \pm 3 \mathrm{Ma}$, which is interpreted to record the time of metamorphism. The chondrite-normalized REE pattern shows a less prominent negative Eu anomaly when compared with cores, which suggests feldspar breakdown during metamorphism. The patterns are slightly depleted in HREE, possibly indicating their sequestration into the scarce metamorphic garnet. These REE patterns are not ultimately indicative of whether the $\mathrm{U} / \mathrm{Pb}$ zircon rim was formed during the eclogites-facies event or the subsequent epidoteamphibolite overprint of the Chuacús complex.

\subsection{Sample 454}

Sample 454 is a banded gneiss associated with two-mica paragneisses. It is composed of abundant Qtz, Omp, Zo, Ttn (no rutile), Grt (only 5-10\%), and Ap. Zircon is accessory and more abundant in quartz-rich bands. Most sodic pyroxene transformed into symplectite. Poikiloblastic plagioclase and amphibole are late phases, and a second generation of blue-green amphibole is nearly fibrous. Garnet is anhedral and underwent resorption. The uncommon mineral assemblage does not correspond to eclogite sensu stricto: quartz is too abundant, titanite is the Ti phase, and garnet is relatively scarce. Nevertheless we interpret the sodic pyroxene and the garnet as phases that grew during the eclogite-facies event, and the symplecite, poikiloblastic amphibole, and plagioclase as phases that grew during amphibolite-facies retrogression.

Zircons are $80-200 \mu \mathrm{m}$ and most show CL core-rim relations (Fig. 3C). Many cores show oscillatory zoning and are otherwise similar to zircon cores in orthogneiss 887c. Four of these cores yielded Triassic U-Pb ages ranging $243-220 \mathrm{Ma}$, consistent with protolith ages of orthogneiss and eclogite. A second group of cores is either featureless or shows faint sector zoning. Three such cores yielded ${ }^{204} \mathrm{~Pb}$-corrected ${ }^{207} \mathrm{~Pb} /{ }^{206} \mathrm{~Pb}$ ages ranging $940-1030 \mathrm{Ma}$ (Fig. 4C). The association of sample 454 with paragneisses and the presence of two zircon-core populations suggest that these are detrital.

Zircon rims are $10-60 \mu \mathrm{m}$, larger than SHRIMP-RG beam size (Fig. 3C). In CL, they are either featureless or show a faint texture continuous with that of the core. Eight rim analyses yielded 7-58 ppm U, $\mathrm{Th} / \mathrm{U}<0.05$, and a mean $\mathrm{U}-\mathrm{Pb}$ age of $74.5 \pm 3.5 \mathrm{Ma}$. Zircon cores contain more abundant chondrite-normalized REE concentrations when compared to rims (Fig. 5). Interestingly, the REE patterns of metamorphic zircon rims show Eu anomaly and are slightly enriched in heavy rare earths. Hence, we interpret these rims as having grown during poikiloblastic plagioclase growth and garnet resorption, i.e., their $\mathrm{U}-\mathrm{Pb}$ age represents the time of amphibolite-facies retrogression. These ages are equivalent to ${ }^{40} \mathrm{Ar} /{ }^{39} \mathrm{Ar}$ ages of amphiboles and micas that define the foliation in Chuacús paragneiss and orthogneiss (Ratschbacher et al., 2009); hence pegmatites that crosscut this penetrative structure are Late Cretaceous or younger (see 2.1).

\section{Discussion}

$\mathrm{Cpx}+\mathrm{Grt}+$ Phg thermobarometry of Chuacús eclogites indicates metamorphism to $660-750^{\circ} \mathrm{C}$ and $21-24$ kbar. Zircon from eclogites hosted in orthogneisses has metamorphic rims that show chondritenormalized REE patterns devoid of Eu anomaly and depressed in HREE. These features suggest that zircon rims grew as part of a garnet- 


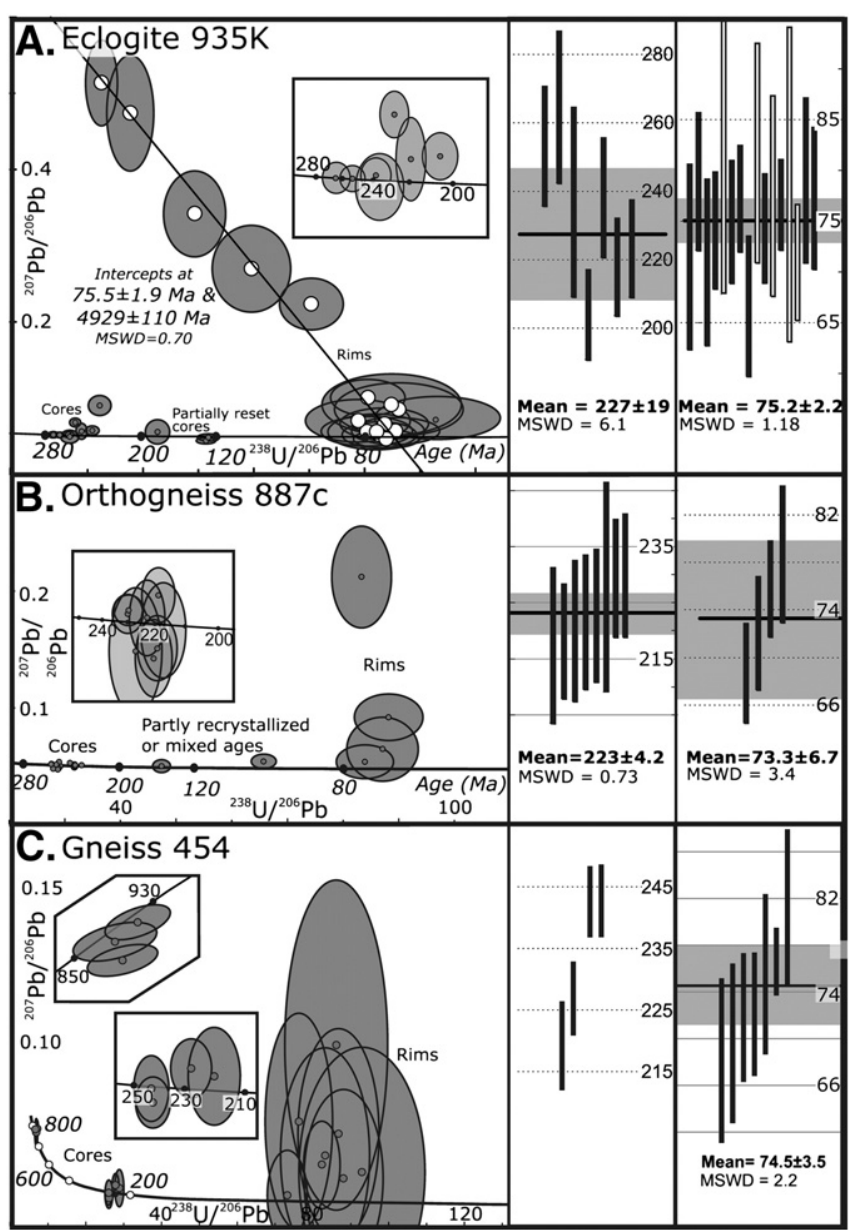

Fig. 4. Tera Wasserburg concordia diagrams (left) and weighted mean ages (right) for zircon. Data error ellipses are $2 \sigma$; where ellipse is not shown, it is smaller than analysis point. Mean ages are weighted by error; shown error bars are at $2 \sigma$ level. (A) Tanilar eclogite $935 \mathrm{~K}$; unfilled error bars correspond to analyses with high ${ }^{204} \mathrm{~Pb}$, which were not considered for mean calculation. (B) Chuacús orthogneiss 887 c. (C) Chuacús gneiss 454.

rich and plagioclase-free paragenesis. Hence their $75.5 \pm 1.9 \mathrm{Ma} \mathrm{U}-\mathrm{Pb}$ age is interpreted as the time of the eclogites-facies event. This proposition is also supported by the Sm-Nd mineral isochron of an eclogite band contained in Chuacús orthogneiss, which yielded an identical age of $77 \pm 13 \mathrm{Ma}$. The Late Cretaceous age for Chuacús eclogites contrasts with previous work proposing the high-pressure event occurred in the Paleozoic (e.g., Ortega-Gutiérrez et al., 2004; Ratschbacher et al., 2009; Solari et al., 2011).

The timing of the extensive amphibolite-facies overprint of the Chuacús complex is constrained by the age of sample 454, the retrogressed omphacite-bearing paragneiss. REE patterns suggest that zircon rims from this gneiss grew during retrogression. Their $74.5 \pm 3.5 \mathrm{Ma} \mathrm{U}-\mathrm{Pb}$ age is equivalent to the $\mathrm{U}-\mathrm{Pb}$ age of the eclogite facies event. Thus, the time difference between these two metamorphic events in the Chuacús complex cannot be fully resolved at the error level of the U-Pb chronologic system. This implies a short-lived metamorphic cycle involving eclogite-facies and subsequent amphibolitefacies crystallization. Quick retrogression is also consistent with the published $\mathrm{K}-\mathrm{Ar}$ and ${ }^{40} \mathrm{Ar} /{ }^{39} \mathrm{Ar}$ cooling ages of amphibole and white mica, reviewed above, that range $\sim 76-62 \mathrm{Ma}$.

Zircon core ages in both orthogneisses and eclogites yield Triassic, $\sim 225 \mathrm{Ma}$ ages. Also paragneisses contain detrital zircon grains with Triassic cores. This result is consistent with previous work (e.g., Ratschbacher et al., 2009; Solari et al., 2011), and it implies that the Chuacús complex contains a significant metaigneous component of this age.
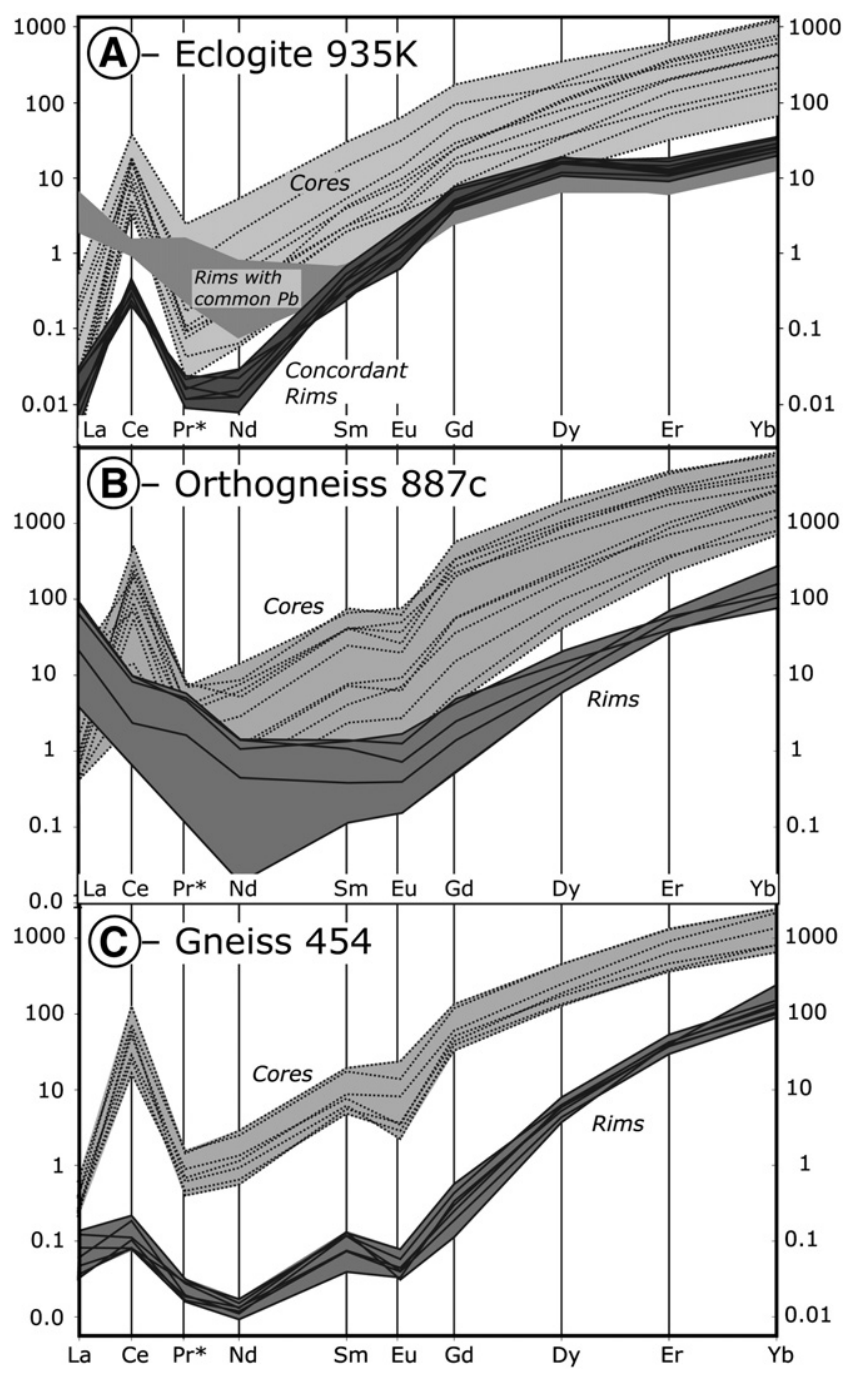

Fig. 5. Chondrite-normalized REE patterns for zircons; normalized to chondrite values of McDonough and Sun (1995).

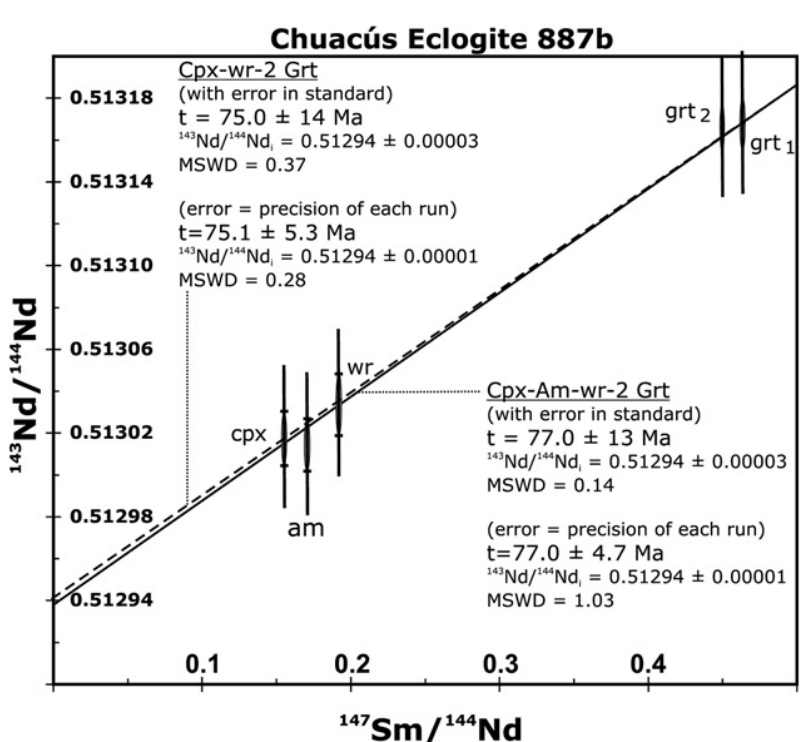

Fig. 6. Sm-Nd mineral-whole rock isochrons of eclogite 887b. Continuous isochron includes amphibole; dotted isochron excludes amphibole. Error ellipses at $2 \sigma$ level. 
The similar protolith age of eclogites and host orthogneisses suggests that high-pressure blocks were not tectonically added to low-pressure gneisses from an exotic block such as the North Motagua mélange. Instead, we propose that a coherent block of Triassic Chuacús granites containing subordinate mafic rocks underwent subsequent eclogite-facies and amphibolite-facies metamorphic events. This feature was best recorded in mafic protoliths, a feature common to most continental slabs that underwent high pressure or ultra-high pressure metamorphism (e.g., Liou et al., 2004).

We conclude that the $75.5 \pm 1.9 \mathrm{Ma}$ age of Chuacús eclogites represents the time of continental subduction of at least part of the southernmost continental margin of the North American plate to $>60 \mathrm{~km}$ depth, along conditions that would occur within a subduction zone with a thermal gradient of $\sim 9-12{ }^{\circ} \mathrm{C} / \mathrm{km}$. The subducted continental slab was quickly exhumed from the mantle to mid-crust level, perhaps as a result of buoyant forces (e.g., Boutelier et al., 2004; Chemenda et al., 1996). Decompression from temperatures of $\sim 660-750{ }^{\circ} \mathrm{C}$ and depths of $65-75 \mathrm{~km}$ was isothermal to depths of $50 \mathrm{~km}$ and cooled only slightly to $500-600^{\circ} \mathrm{C}$ at depths of $20-30 \mathrm{~km}$ (Fig. 8 in Ratschbacher et al., 2009). Rapid exhumation presumably allowed the Chuacús complex to remain hot during exhumation allowing for the production of pegmatites by isothermal decompression.

\subsection{Links between the metamorphic and sedimentary records of Late Cretaceous collision}

North of the GSC, the Campanian Campur Formation registers the transition from shelf to deep fan beds, a process interpreted to record onset of foreland basin formation by tectonic loading during collision/ subduction of southernmost North America with either the Greater Caribbean Arc, the Nicaragua Rise, or the Chortís block (Fourcade et al., 1994; Ortega-Obregón et al., 2008; Pindell and Kennan, 2009; Ratschbacher et al., 2009). Here we have shown that this event was contemporaneous with eclogite-facies metamorphism of the Chuacús complex. We conclude that Late Cretaceous collision not only involved tectonic loading and lithospheric flexure of North America's continental shelf but continental subduction of the plate's leading edge into the mantle.

\subsection{Initial juxtaposition of the Chuacús complex and the North Motagua mélange}

The GSC north of the Cabañas fault contains two high-pressure belts juxtaposed by strike-slip and thrust faults: the North Motagua serpentinite mélange hosting eclogites that record Early Cretaceous (Neocomian) subduction of oceanic crust (Brueckner et al., 2009) and the Chuacús complex with eclogites recording Late Cretaceous (Campanian) subduction of continental crust. The time of juxtaposition of these high-pressure belts is a matter of debate. Most authors argue that they underwent independent geologic histories in the Mesozoic and their juxtaposition was a result of Tertiary transpression and local thrust faulting within the Motagua Fault system (e.g., Francis, 2005; Giunta et al., 2002). In contrast, Brueckner et al. (2009) suggested that a Late Cretaceous link between the Chuacús complex and the exotic blocks hosted in the North Motagua mélange was inescapable because of their overlapping $\mathrm{K}-\mathrm{Ar}$ and ${ }^{40} \mathrm{Ar} /{ }^{39} \mathrm{Ar}$ ages.

Supporting the Brueckner et al. (2009) model, Late Cretaceous juxtaposition of oceanic and continental high-pressure belts is implied by the presence of a pegmatite that intrudes a serpentinite of the North Motagua mélange. As explained in Section 2.1., this pegmatite constitutes one of a series of late- to post-tectonic intrusions, which we suggest originated from partial melting of Chuacús gneisses during adiabatic decompression. Partial melting is a common feature of deep and hot continental slabs that decompress quickly (e.g., Whitney et al., 2004). The presence of at least one of these pegmatites within the North Motagua mélange suggests that the oceanic and continental high-pressure belts of the GSC must have been juxtaposed at this time. This contention is consistent with the pegmatite's 75-66 Ma cooling ages. We hypothesize that exhumation of the hot Chuacús slab not only generated partial melts but also provided the heat necessary to overprint the high-pressure assemblages in the North Motagua mélange. This is why the $\mathrm{K}-\mathrm{Ar},{ }^{40} \mathrm{Ar}-39 \mathrm{Ar}$ and $\mathrm{Rb}-\mathrm{Sr}$ mineral ages of the pegmatites and the high-pressure blocks within the mélange are coeval.

\subsection{Other evidence of continental subduction in the northern Caribbean}

Several geologic features indicate that Late Cretaceous continental subduction and collision are not local features of the Chuacús complex but that suturing involved a significant portion of the North AmericaCaribbean plate boundary. East of Guatemala, García-Casco et al. (2008) identified various units of continental metasedimentary rocks that were involved in Late-Cretaceous subduction. These were grouped into the Caribeana terrane, which includes the Cangre, Pinos, Escambray, Asunción, and Samaná units of Cuba and Hispaniola. West of Guatemala in the Late Cretaceous, the collision zone is well recorded by the arc rocks of the Siuna belt of Nicaragua that collided with a south- or south-west facing continental margin of the Chortis block producing the northwestward-transported Colon fold-thrust belt (Rogers et al., 2007).

\subsection{Tectonic model}

The following tectonic model for the Late Cretaceous is based on the work of Pindell and Kennan (2009), and it borrows from Rogers et al. (2007) and the similar model in Ratschbacher et al. (2009). The disputed origin of eclogites of the North Motagua mélange in an Early Cretaceous subduction zone associated with the Chortís block (Brueckner et al., 2009) or the Caribbean Arc (Pindell and Kennan, 2009; Pindell et al., 2012; Ratschbacher et al., 2009) is immaterial for the model below.

From Middle to Late Cretaceous, a southwest-dipping subduction zone under the Greater Antilles Arc consumed the oceanic crust of the Proto-Caribbean, eventually bringing the passive margin of the Maya Block (North America) to the trench (Fig. 7A). Campanian collision is recorded by a number of features: 1 ) crustal loading by the upper plate caused plate flexure in the lower plate, which deepened the continental platform during the deposition of the Campur Formation ultimately resulting in the Sepur foredeep (e.g., Pindell and Kennan, 2009, and references therein); 2) Late Cretaceous metamorphism of sedimentary cover rocks with steep PT gradients throughout the northern Caribbean (García-Casco et al., 2008); 3) subduction of continental basement of North America beneath the Greater Antilles Arc or the Nicaragua Rise to at least $60 \mathrm{~km}$ depth in the mantle, generating eclogites within the continental Chuacús gneisses (this work).

Quickly after subduction, the hot subducted continental slab (Fig. 7C) was uplifted to crustal level resulting in amphibolite-facies recrystallization and the formation of partial melts, possibly by decompression. Some of the melts migrated and intruded the subduction mélange of the overriding plate, which contained blocks of oceanic eclogites formed in the Early Cretaceous. These older eclogites had their $\mathrm{K}-\mathrm{Ar}$ and ${ }^{40} \mathrm{Ar}-{ }^{39} \mathrm{Ar}$ (but not their Sm-Nd) ages reset by the Late Cretaceous overprint under amphibolite-facies conditions. We propose that this overprint was caused by the exhumed continental slab, which transferred heat from deeper portions to shallower portions of the subduction channel. Late in the orogenic cycle, thrust sheets continued to advance northward. Harzburgite-dominated ophiolitic nappes were emplaced over unmetamorphosed sedimentary rocks of the continental shelf and foredeep generating a thrust and fold belt in northern Guatemala. Thrusting continued into the earliest Paleogene as constrained by the youngest sedimentary unit involved in 


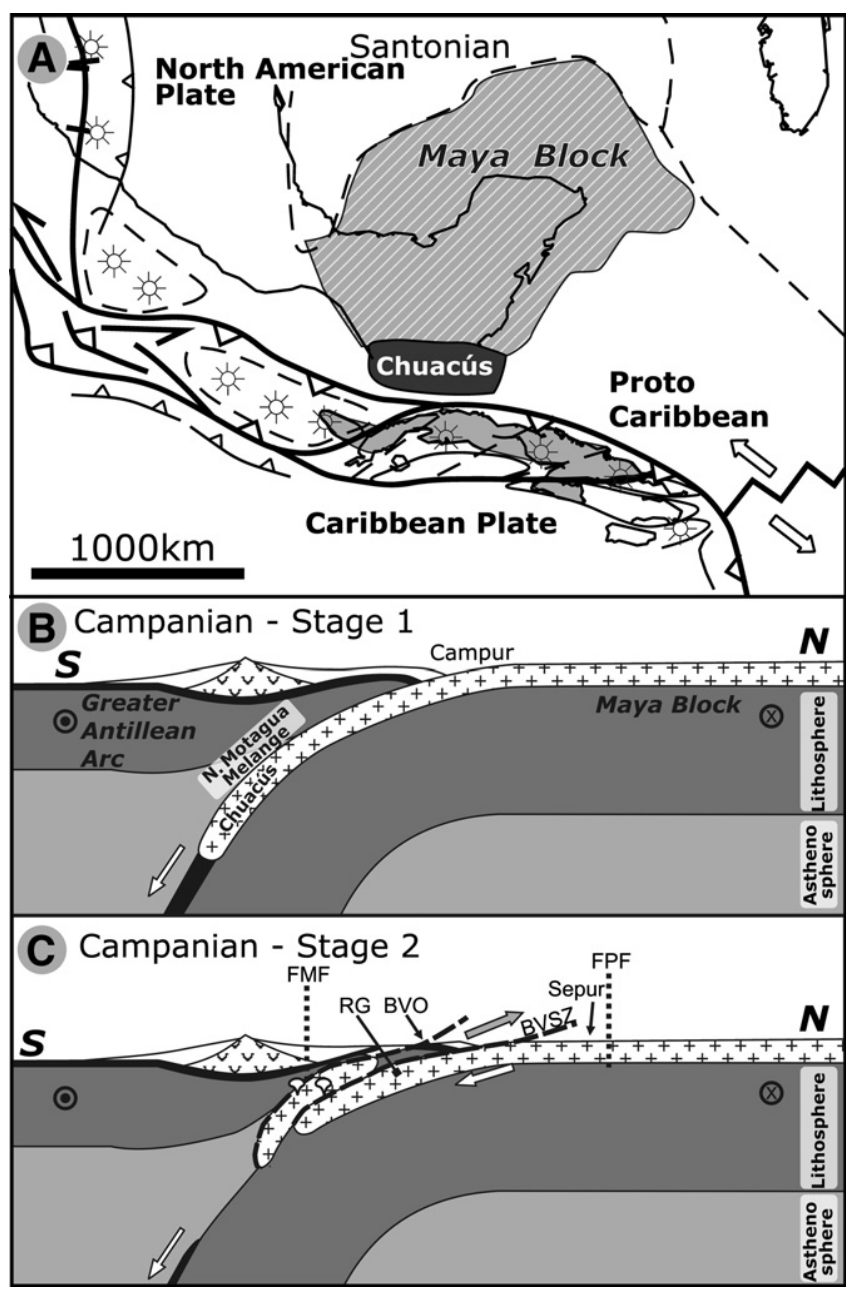

Fig. 7. Tectonic reconstruction modified from Pindell and Kennan (2009). (A) In the Santonian ( 84 Ma), the passive continental margin of the Maya Block (North America) was about to reach the trench produced by ongoing subduction of Proto-Caribbean crust under the active Greater Antilles Arc. Dark gray area is the portion of the continental Maya Block (future Chuacús) that will subduct in the Campanian. (B) Cross section of Campanian collision, stage 1: subduction and eclogite-facies metamorphism of the Chuacús slab coeval with deepening of the continental platform and deposition of the Campur Fm. (C) Cross section of Campanian collision, stage 2: exhumation and amphibolite-facies metamorphism of the Chuacús slab, pegmatite intrusions into Chuacús and the North Motagua mélange, and northward advance of ultramafic thrust sheets. Abbreviations: $\mathrm{FMF}=$ future Motagua Fault; $\mathrm{RG}=$ Rabinal granite; $\mathrm{BVO}=\mathrm{Baja}$ Verapaz ophiolite; BVSZ = Baja Verapaz shear zone; FPF $=$ future Polochic Fault.

deformation, which, in Guatemala, is the Maastrichtian-Danian Sepur flysch.

Supplementary materials related to this article can be found online at doi:10.1016/j.lithos.2012.04.021.

\section{Acknowledgments}

This work was funded by NSF Grants EAR 0510325 to J.G. Liou, EAR 0309832 to H.K. Brueckner, and the Stanford McGee Fund to U. Martens. This project is part of IGCP Project 546 on "Subduction Zones of the Caribbean." It is contribution 7546 of Lamont-Doherty Earth Observatory of Columbia University. Gratitude is expressed to B. Jones, who extensively helped during microprobe analysis, J. Padilla for fieldwork assistance, and to W.G. Ernst and Antonio García-Casco who revised an early draft of the manuscript. Brad Hacker and Lothar Ratschbacher are thanked for their constructive criticism of an initial version of the manuscript, and Walter Maresch for reviewing the final version of the article.

\section{References}

Beccaluva, L., Bellia, S., Coltorti, M., Dengo, G., Giunta, G., Mendez, J., Romero, J., Rotolo, S Siena, F., 1995. The northwestern border of the Caribbean Plate in Guatemala; new geological and petrological data on the Motagua ophiolitic belt. Ofioliti 20,1-15.

Black, L.P., Kamoc, S.L., Allen, Ch.M., Davis, D.W., Aleinikoff, J.N., Valley, J.W., Mundil, R., Campbell, I.H., Korsch, R.J., Williams, I.S., Foudoulis, C., 2004. Improved ${ }^{206} \mathrm{~Pb} /{ }^{238} \mathrm{U}$ microprobe geochronology by the monitoring of a trace-element-related matrix effect; SHRIMP, ID-TIMS, ELA-ICP-MS and oxygen isotope documentation for a series of zircon standards. Chemical Geology 205, 115-140.

Bonis, S., Bohnenberger, O., Dengo, G., 1970. Mapa geológico de la República de Guatemala. Instituto Geológico Nacional. 4 sheets.

Bonis, S., 1993. Mapa geológico general de Guatemala, Hoja Guatemala 1 : 250000. Instituto Geográfico Militar, Guatemala. 1 sheet.

Boutelier, D., Chemenda, A., Jorand, C., 2004. Continental subduction and exhumation of high-pressure rocks: insights from thermo-mechanical laboratory modelling. Earth and Planetary Science Letters 222, 209-216.

Brueckner, H.K., Avé Lallemant, H.G., Sisson, V.B., Harlow, G.E., Hemming, S.R., Martens, U., Tsujimori, T., Sorensen, S.S., 2009. Metamorphic reworking of a high pressurelow temperature mélange along the Motagua fault, Guatemala: a record of Neocomian and Maastrichtian transpressional tectonics. Earth and Planetary Science Letters 284, 228-235.

Carswell, D.A., Wilson, R.N., Zhai, M., 2000. Metamorphic evolution, mineral chemistry and thermobarometry of schists and orthogneisses hosting ultra-high pressure eclogites in the Dabieshan of central China; ultra-high pressure metamorphic rocks. Lithos 52, 121-155.

Chemenda, A.I., Mattauer, M., Bokun, A.N., 1996. Continental subduction and a mechanism for exhumation of high-pressure metamorphic rocks: new modeling and field data from Oman. Earth and Planetary Science Letters 143, 173-182.

Dengo, G., 1969. Problems of tectonic relations between Central America and the Caribbean. Transactions of the Gulf Coast Association of Geological Societies 29, 311-320.

Endo, S., Wallis, S.R., Tsuboi, M., Torres De León, R., Solari, L.A., 2012. Metamorphic evolution of lawsonite eclogites from the southern Motagua fault zone, Guatemala: insights from phase equilibria and Raman spectroscopy. Journal of Metamorphic Geology 30, 143-164.

Francis, A. H., 2005. Deformation History of the Maya and Chortís Blocks: Insight to the Evolution of the Motagua Fault Zone, Guatemala. M Sc thesis, Rice University, Houston, 89p.

Fourcade, E., Mendez, J., Azema, J., Bellier, J., Cros, P., Michaud, F., Carballo, M., Villagran, J.C., 1994. Dating of the settling and drowning of the carbonate platform, and of the overthrusting of the ophiolites on the Maya Block during the Mesozoic (Guatemala). Newsletters on Stratigraphy 30, 33-43.

Fourcade, E., Piccioni, L., Escriba, J., Rossello, E., 1999. Cretaceous stratigraphy and palaeoenvironments of the southern Peten Basin, Guatemala. Cretaceous Research 20, 793-811.

Ganguly, J., Chakraborty, S., Sharp, T.G., Rumble III, D., 1996. Constraint on the time scale of biotite-grade metamorphism during Acadian Orogeny from a natural garnet-garnet diffusion couple. American Mineralogist 81, 1208-1216.

García-Casco, A., Iturralde-Vinent, M.A., Pindell, J., 2008. Latest Cretaceous collision/accretion between the Caribbean Plate and Caribeana: origin of Metamorphic Terranes in the Greater Antilles. International Geology Review 50, 781-809.

Giunta, G., Beccaluva, L., Coltorti, M., Cutrupia, D., Dengo, C., Harlow, G.E., Mota, B., Padoa, E., Rosenfeld, J., Siena, F., 2002. The Motagua suture zone in Guatemala. Ofioliti 27, 47-72

Harlow, G.E., Hemming, S.R., Avé Lallemant, H.G., Sisson, V.B., Sorensen, S.S., 2004. Two highpressure-low-temperature serpentinite-matrix mélange belts, Motagua fault zone Guatemala: a record of Aptian and Maastrichtian collisions. Geology 32, 17-20.

Holland, T.J.B., 1990. Activities of components in omphacitic solid solutions; an application of Landau theory to mixtures. Contributions to Mineralogy and Petrology 105 446-453.

Holland, T.J.B., Powell, R., 1998. An internally consistent thermodynamic data set for phases of petrological interest. Journal of Metamorphic Geology 16, 309-343.

Krogh-Ravna, E.J., Terry, M.P., 2004. Geothermobarometry of UHP and HP eclogites and schists-an evaluation of equilibria among garnet-clinopyroxene-kyanite-phengite-coesite/quartz. Journal of Metamorphic Geology 22, 579-592.

Liou, J.G., Tsujimori, T., Zhang, R.Y., Katayama, I., Maruyama, S., 2004. Global UHP metamorphism and continental subduction/collision: the Himalayan model. International Geology Review 46, 1-27.

Ludwig, K.R., 2001. Squid 1.02: a user's manual. Berkeley Geochronology Center Special Publication, 2. $19 \mathrm{pp}$.

Ludwig, K.R., 2003. User's manual for Isoplot 3.00: a geochronological toolkit for Microsoft Excel. Berkeley Geochronology Center Special Publication, 4. 70 pp.

Martens, U., 2009. Geologic evolution of the Maya Block: an example of terrane transferral and crustal recycling [Ph.D. Thesis]. Stanford University, Stanford, CA, United States.

Mattinson, C.G., Wooden, J.L., Liou, J.G., Bird, D.K., Wu, C.L., 2006. Age and duration of eclogite-facies metamorphism, North Qaidam HP/UHP terrane, western China. American Journal of Science 306, 683-711.

McDonough, W.F., Sun, S., 1995. The composition of the Earth. Chemical Geology 120, 223-254.

Michaud, F., Fourcade, E., Azema, J., Carballo Hernandez, M.A., Franco Austin, J.C., 1992. The Middle and Upper Cretaceous of the southern part of the Maya Block, Guatemala. Journal of South American Earth Sciences 5, 229-236.

Neuhuber, S., Wagreich, M., 2008. Late Campanian Sr, C, and O Isotopes Recorded from the Globotruncanita Calcarata Zone (Austrian Alps). Geophysical Research Abstracts, 10. EGU2008-A-06433. 
Ortega-Gutiérrez, F., Solari, L.A., Sole, J., Martens, U., Gomez-Tuena, A., Morán-Ical, S. Reyes-Salas, M., Ortega-Obregón, C., 2004. Polyphase, high-temperature eclogitefacies metamorphism in the Chuacus Complex, central Guatemala; petrology, geochronology, and tectonic implications. International Geology Review 46, 445-470.

Ortega-Obregón, C., Solari, L.A., Keppie, J.D., Ortega-Gutiérrez, F., Sole, J., Moran-Ical, S 2008. Middle-Late Ordovician magmatism and Late Cretaceous collision in the southern Maya Block, Rabinal-Salama area, central Guatemala; implications for North America-Caribbean Plate tectonics. Geological Society of America Bulletin $120,556-570$.

Pindell, J., Kennan, L, 2009. Tectonic evolution of the Gulf of Mexico, Caribbean and northern South America in the mantle reference frame: an update. In: James, K., Antonieta-Lorente, M., Pindell, J. (Eds.), The Geology and Evolution of the Region between North and South America: Geological Society of London Special Publication, 328, pp. 1-55.

Pindell, J. Maresch, W.V., Martens, U., Stanek, K., 2012. The Greater Antillean Arc: early Cretaceous origin and proposed relationship to Central American subduction mélanges: implications for models of Caribbean evolution. International Geology Review 54, 131-143.

Plafker, G., 1976. Tectonic aspects of the Guatemala earthquake of 4 February 1976 . Science 193, 1201-1208.

Proyer, A., Dachs, E., McCammon, C., 2004. Pitfalls in geothermobarometry of eclogites: $\mathrm{Fe}^{+3}$ and changes in the mineral chemistry of omphacite at ultrahigh pressures. Contributions to Mineralogy and Petrology 147, 305-318.

Puckett, T.M. Mancini. E.A., 1998. Planktic foraminiferal Globotruncanita calcarata tota range zone; its global significance and importance to chronostratigraphic correlation in the Gulf Coastal Plain, USA. Journal of Foraminiferal Research 28, 124-134.

Ratschbacher, L., Franz, L., Min, M., Bachmann, R., Martens, U., Stanek, K., Stübner, K. Nelson, B.K., Herrmann, U., Weber, B., López-Martínez, M., Jonckheere, R. Sperner, B., Tichomirowa, M., Mcwilliams, M.O., Gordon, M., Meschede, M., Bock, P., 2009. The North American-Caribbean Plate boundary in Mexico-GuatemalaHonduras. In: James, K., Antonieta-Lorente, M., Pindell, J. (Eds.), The Geology and Evolution of the Region between North and South America: Geological Society of London Special Publication, 328, pp. 219-293.

Rogers, R., Mann, P. Emmet, P. A, Venable, M.E. 2007. Colon fold belt of Honduras: evidence for Late Cretaceous collision between the continental Chortis block and intra-oceanic Caribbean arc. In: Mann, P. (Ed.), Geologic and Tectonic Development of the Caribbean Plate in Northern Central America: Geological Society of America Special Paper, 428, pp. 129-149.

Rosencrantz, E., Mann, P.. 1991. SeaMarc II mapping of transform faults in the Cayman Trough, Caribbean Sea. Geology 19, 690-693.

Rosencrantz, E., Sclater, J.G., 1986. Depth and age in the Cayman Trough. Earth and Planetary Science Letters 79, 133-144.
Rosenfeld, J.H., 1981. Geology of the western Sierra de Santa Cruz, Guatemala, Centra America; an ophiolite sequence [Ph.D. Thesis]. United States (USA), SUNY, Binghamton University, Binghamton, NY, United States.

Sapper, K.T., 1899. Ueber Gebirgsbau und Boden des noerdlichen Mittelamerika. Petermanns Geographische Mitteilungen. (119 pp.).

Schwartz, D.P., Cluff, L.S., Donnelly, T.W., 1979. Quaternary faulting along the Caribbean-North American plate boundary in Central America. Tectonophysics 52 , 431-445.

Siivola, J., Schmid, R., 2007. Recommendations by the IUGS Subcommission on the Systematics of Metamorphic Rocks: list of mineral abbreviations. IUGS Commission on the Systematics in Petrology. Web http://www.bgs.ac.uk/scmr/ docs/papers/paper_12.pdf.

Solari, L.A., Gómez-Tuena, A., Ortega-Gutiérrez, F., Ortega-Obregón, C., 2011. The Chuacús Metamorphic Complex, central Guatemala: geochronological and geochemical constraints on its Paleozoic-Mesozoic evolution. Geologica Acta 9 , 329-350.

Sutter, J., 1979. Late Cretaceous collisional tectonics along the Motagua fault zone, Guatemala. GSA Abstracts with Programs, 11, pp. 525-526.

Tsujimori, T., Liou, J.G., Coleman, R.G., 2004. Comparison of two contrasting eclogites from the Motagua fault zone, Guatemala: southern lawsonite eclogite versus northern zoisite eclogite. Geological Society of America Abstracts with Programs 36, 136.

Tsujimori, T., Sisson, V.B., Liou, J.G., Harlow, G.E., Sorensen, S.S., 2006. Petrologic characterization of Guatemalan lawsonite eclogite; eclogitization of subducted oceanic crust in a cold subduction zone. In: ultrahigh-pressure metamorphism: deep continental subduction. In: Hacker, B., McClelland, W.C., Liou, J.G. (Eds.), Special Paper - Geological Society of America, 403, pp. 147-168.

van den Boom, G., 1972. Petrofazielle Gliederung des metamorphen Grundgebirges in der Sierra de Chuacús, Guatemala. Beihefte zum Geologischen Jahrbuch 122, $49 \mathrm{pp}$.

Vinson, G.L., 1962. Upper Cretaceous and Tertiary stratigraphy of Guatemala. Bulletin of the American Association of Petroleum Geologists 46, 425-456.

Whitney, D.A., Teyssier, C., Fayon, A.K., 2004. Isothermal decompression, partial melting and exhumation of deep continental crust. Vertical coupling and decoupling in the lithosphere: Geological Society Special Publications, 227, pp. 313-326.

Wilson, H.H., 1974. Cretaceous Sedimentation and Orogeny in Nuclear Central America. American Association of Petroleum Geologists Bulletin 58, 1348-1396.

York, D., 1969. Least-squares fitting of a straight line with correlated errors. Earth and Planetary Science Letters 5, 320-324. 